\title{
6.14 Компьютер - оқушының математиканы оқып-білу іс-әрекетінің негізгі бір құралы
}

Жаңа ақпараттық технологиялар дегеніміз - білім беру ісінде ақпараттарды даярлап, оны білім алушыға беру үрдісі. Бұл үрдісті іске асыруда негізгі құрал компьютер болып табылады. Компьютер - білім беру ісіндегі бұрын шешімін таппай келген жаңа, тың дидактикалық мүмкіндіктерді шешуге мүмкіндік беретін зор құрал. Бірақ, әлі күнге дейін біз осы зор құралдың шексіз мүмкіндіктерінің оннан бірін де пайдалана алмай отырмыз.

Жаңа ақпараттық технологияларды тиімді түрде пайдаланудың негізгі шарты - дербес компьютерлердің орны мен рөлін дұрыс анықтау болып табылады, ол информатика сабағында ғана қолданылумен шектелмеуі тиіс.

Компьютерді оқу үрдісінде қолдану проблемаларының ішінен екі бағытты бөліп алуға болады, олардың біріншісі - компьютерлік сауаттылықты қамтамасыз ету, бұл жағдайда компьютер зерттеу объектісі болып табылады, екіншісі - компьютерді оку құралы ретінде пайдалану.

Екінші бағыт шеңберінде компьютер оқыту құралдары жүйесінің белгілі бір компоненті деп есептеледі.

Оқытудың осындай құралдар жүйесі оқу әдістемелік әдебиет пен курсты программалық қамтамасыз ету жағынан оқу-әдістемелік кешен (ОӘК) болып табылады. Мұнда ЖАТ пайдалану құралы болып табылатыны сөзсіз. И.В.Роберт атап өткендей, ОӘК компонеттерінің құраушыларының қатынасын және оның құрамын анықтау - келешектің ісі [492].

Математиканы оқып үйренуге арналған ОӘК -нің жобамен анықталған құралы 2- суретте көрсетілген.

Әдеттегі оқу құралдарын пайдаланудың қажеттілігі арнайы функцияларды қажет етеді, ал оны компьютердің мойнына жүктеу тиімсіз болады.

Мысалы, оқушылардың есінде сақтауға қажетті формулаларды, жүйеленген теориялық және анықтамалық мәліметтерді кестелер мен сызба түрінде ұсыну керек. Әрбір сабақта жүйелі түрде кестеде көрсетілген материалды оқушы жаттай береді. Компьютер бұл жағдайда тиімсіз болады. Егер 
анықтамалық материал қысқа мерзім ішінде пайдалануға қажет болса және есте сақтауды қажет етпесе, онда ақпараттық-іздестіру жүйесін қолданған дұрыс.

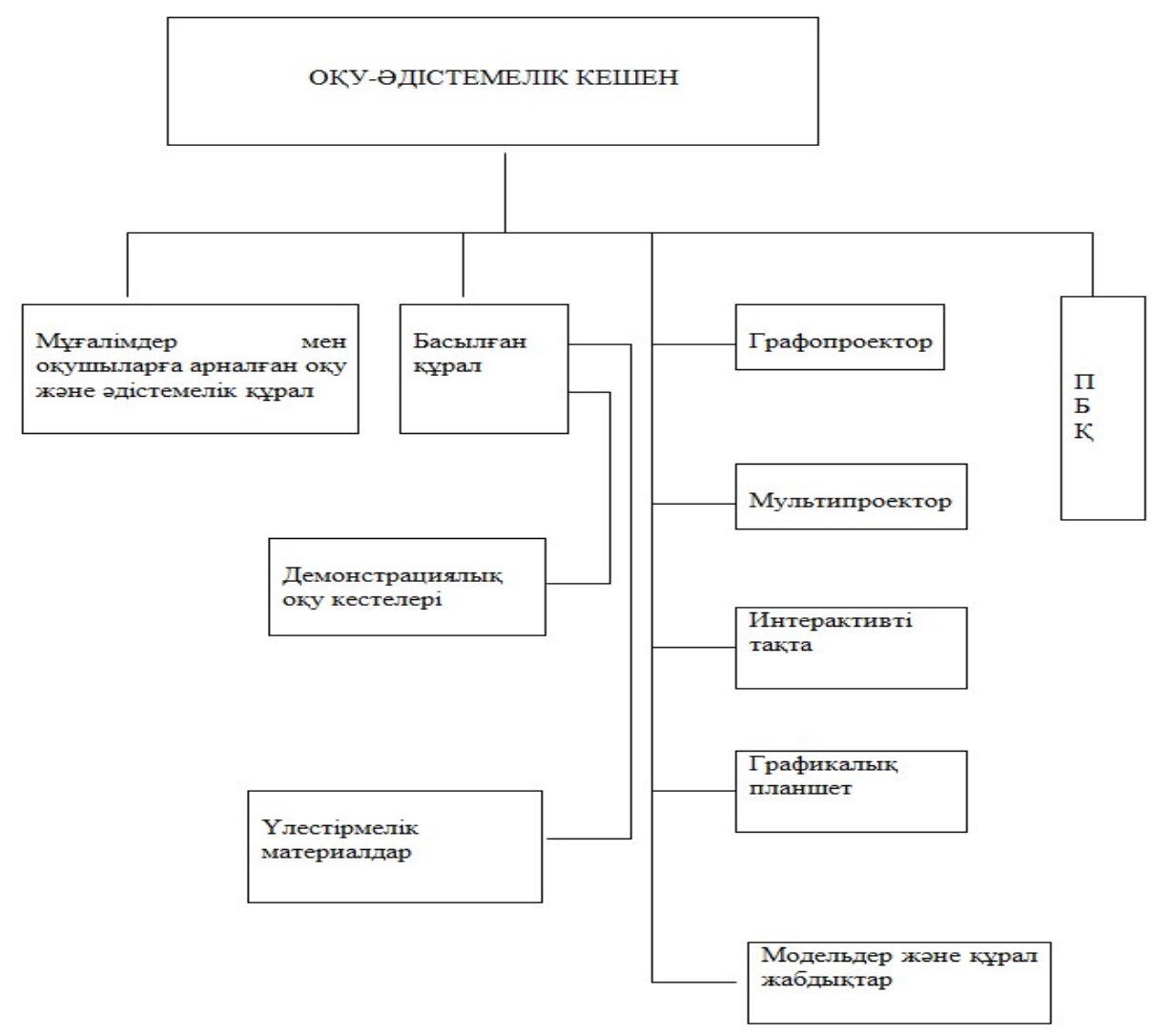

Сурет 1. Математиканы оқып үйренуге арналған ОӘК-ң сызба нұсқасы

Компьютерді оқу үрдісінде қолдану мәселелерін қарастырғанда оның екі функцияны атқаратынын ескеру қажет, олар: оқыту іс-әрекетінің құралы және оқу құралы.

Егер компьютер оқу іс-әрекеті құралы ретінде пайдаланылатын болса, онда оның қызметтерінің басқа бір іс-әрекеттерден аз ғана айырмашылығы болады, яғни оқушының компьютермен іс-әрекеті «Компьютерді пайдаланушы» деген өзара әрекеттестік схемасынан аспайды.

Дербес компьютерлердің адамдар іс-әрекетіндегі құрал ретіндегі және жаңа оқу құралы ретіндегі негізгі ерекшеліктері [493], [494] еңбектерінде көрсетілген. Аталған еңбектерді талдау компьютердің келесі ерекшеліктерін атап көрсетуге мүмкіндік береді:

- көлемі шектелмеген ақпаратқа және оны аналитикалық түрде өңдеуге қол жеткізуді қамтамасыз етеді: 
- адамның танымдық-зерттеу іс-әрекетінде әмбебап құрал ретінде пайдаланылады;

- психикалық іс-әрекет өнімдерін бекітудің жаңа белсенді формасын қамтамасыз етеді, білімнің жеке аспектілерін талдау сияқты түрлендірулерді дербес түрде автоматтандырады және оны толыққанды түрде орындайды, қолда бар мәліметтермен салыстырады, белгілі бір саланы жаңа ақпаратпен толықтырады, сонымен қатар, практикалық іс-әрекеттерді ұйымдастыруда пайдаланылады;

- әдеттегі жазбалардан кейінгі екінші саптағы мәні бар белгілі құрал болып табылады, оның көмегімен орындалатын іс- әрекеттің мазмұны бойынша жедел түрде ақпарат алмасуға болады;

- адамдар іс- әрекетіндегі қолданылатын саймандар мен құралдардың арасындағы байланыстарды орнату негізінде мағыналы заттық- бағыттық орта ретіндегі ерекшеліктері болады.

Компьютер қай уақытта оқу іс-әрекетінің құралы, қай уақытта оқыту құралы ретінде пайдаланылатындығын қалай ажыратуға болады? Компьютер және оны басқару іс-әрекеттерінде оқушымен шешілетін мәселе және қандай да бір оқу мақсаттары ескерілген жағдайда ғана дидактикалық қызметтер жүргізеді. Мысалы, эксперттік жүйелерді алайық. Оларда басқару жүйелері пәндік мәселелерді шешуге арналған, ал бұл жерде ешқандай оқу мақсаттары есепке алынбайды. Бұл жағдайда компьютер оқу құралы болады деп есептеуге негіз жоқ.

Е.И.Машбиц [495] компьютерлік оқытудың екі типін бөліп көрсетеді. Бірінші тип - оқушы мен компьютердің өзара іс-әрекетімен сипатталынады. Екінші типке компьютер мен педагогтың өзара іс-әрекеті жатады. Мұғалім компьютерді пайдалана отырып, оқыту нәтижесін тексеру арқылы оқыту үрдісін басқаруға мүмкіндік алады. Осылайша оқу үрдісін біліктілікпен анықтауға, жеке адамды оқытудың тиімді әдістерін және алынған мәліметтерді пайдалана отырып, оны оқытудың стратегиясын қалыптастыруға мүмкіндік тудырады. 
Шетелдерде компьютермен оқытудың екінші типіне көптеген жұмыстар арналған сонымен қатар, мамандар компьютерді екінші типте қолданылуына болашақта көптеген мүмкіндік бар екенін пайымдайды.

Оқып үйренушілердің қолдануына арналған компьютерлік жүйелер негізінен төмендегідей үш қызметті атқарады:

1) деректер базасын жүргізу: оқытылып жатқаны туралы, оқыту кезеңі туралы, оқу бағдарламалары жөнінде, оқу пәндері жөнінде т.с.с.;

2) оқыту жөніндегі деректерді өңдеу: оларды енгізу, ақпараттарды жинақтау, оны сұрыптау және статистикалық амалдар негізінде өңдеу;

3) нәтижелерді анықтау: нақты оқып-үйренушілердің көрсеткіштері туралы, окушылар тобының орта көрсеткіштері, оқу курсының жекелеген бөлімдерінің өту нәтижелері т.б. туралы.

[496], [497] зерттеулерді талдау нәтижелері оқыту үрдісінде компьютерді пайдалану негізінен төмендегі төрт типті есептерді шешуге бағытталатынын көрсетіп отыр.

Біріншіден, компьютер осы уақытқа дейін белгілі дидактикалық есептер жүйесін шешудегі тиімді көмекші құрал ретінде пайдаланылады. Бұл типтегі компьютерлік оқыту бағдарламасының мазмұны - анықтамалық мәліметтер, нұсқаулар, есептеу амалдары, демонстрациялар т.с.с. болады.

Екіншіден, компьютер машиналық емес оқытудың мақсаттары мен міндеттерін және жалпы құрылымын сақтай отырып, жеке дидактикалық есептерді шешу жүктелетін құрал бола алады. Компьютер бұл жағдайда бақылаушының, жаттықтырушының т.с.с. міндеттерін атқарады.

Үшіншіден, әдеттегі жағдайларда шешілмейтін дидактикалық есептерді ұсынуға және оларды шығара білуге мүмкіндік тудырады. Оның мысалы ретінде эксперименттерді жүргізуді имитациялайтын компьютерлік бағдарламаларды алуға болады.

Төртіншіден, компьютер меңгерілуге тиісті обьектілер мазмұнын құрастыру жолдарымен модельдеуге арналған құрал ретінде қолданылады. Бұл кезде оқытудың жаңа стратегиясы жүзеге асады. Бұл бағыттағы 
компьютерлендіру облысындағы өңдемелердің бірі ретінде "компьютерлік оқыту ортасын " алуға болады. Жоғарыда айтылғандарды ескере отырып, математиканы мектепте оқып үйретуде компьютерді қолданудың бағдарламалық-әдістемелік бағыттарын бөліп көрсетуге болады, олар:

1) компьютерлік оқулықтар;

2) пәндік-бағытталған орталар;

3) лабораториялық практикумдар;

4) жаттықтырушылар;

5) бақылаушы бағдарламалар;

6) ақпараттық-анықтамалық жүйелер.

Компьютерлік оқулық (КО) - ол белгілі бір курсты немесе оның үлкен бір бөлігін өз бетімен оқып үйренуге арналған программалық-әдістемелік кешен. КО әдеттегі оқулықтың, анықтамалықтың, есептер жинағының және лабораториялық практикумның қасиеттерін қамтиды. Бұл жағдайда КО аталған оқу құралдарымен салыстырғанда төмендегідей жетістіктерге ие болады:

- әрбір жекелеген пайдаланушыға оқушының теориялық курсты меңгерудегі әр түрлі жұмыс формаларының көлемі мен ретін ыңғайлы түрде анықтауына, мысалдарды талдай алуына, типтік есептерді шығару әдістерін үйренуіне, өз бетімен зерттеу жұмыстарын жүргізе білуіне және одан кейінгі танымдық іс-әрекетінің қалыптасуына жағдай тудырады;

- алған білімдері мен қалыптасқан дағдыларының сапасын өз бетімен бақылай алу мүмкіндігін қамтамасыз етеді;

- зерттеушілік іс- әрекетінің дағдыларын қалыптастырады;

- оқушының белгілі бір курсты меңгеруіне арналған уақытты үнемдейді.

Компьютерлік оқулық дискеттер жиынтығы бар кітап түрінде таратылуы тиіс. Кітап белгілі бір курсты меңгеруге арналған жетекші құрал ретінде жасалып, төмендегідей мәселелерді қамтуы қажет:

- теорияны, мысалдарды, есептерді шығару әдістерін түсіндіру;

- программалық өнімдермен жұмыс істеуге арналған нұсқаулар; 
- кешеннің программалық бөлігімен жұмыс жасауға арналған барлық нұсқаулар;

- алған білімді бақылау құралдары.

Компьютерлік оқулыққа қосымша берілген дискеттер курсты меңгеруге қажетті әр түрлі типті оқыту бағдарламаларын қамтуы мүмкін.

Лабораториялық практикум: бұл типтегі программалар математикалық эксперименттер жүргізуге, обьектілерді, олардың арасындағы өзара байланыстарды немесе олардың кейбір қасиеттерін бақылауға, бақылау нәтижелерін өңдеуге, оларды сандық немесе графиктік түрде ұсынуға және практикада осы объектілерді пайдаланудың әр түрлі аспектілерін зерттеуге бағытталған.

Окушылардың осындай бағдарламаларды пайдалану жөніндегі icәрекеттерін ұйымдастыру үшін эксперименттің мақсаты айқын болуы керек, сол сияқты эксперимент жүргізудің құралдары мен әдістемелері, эксперименттің нәтижесінде алынған нәтижелерді өңдеу мен талдау әдістері нақты түрде анықталуы тиіс. Құжаттарда есеп берудің формалары және мысалдары келтіріліп, оларды толық орындауды қамтамасыз ететін әдістемелік талаптар (жұмысты орындау үлгісі) келтірілуі тиіс.

Жаттықтырушылар есеп шығару дағдыларын өңдеу мен бекітуге арналады. Олар оқушыларды есеп шығарудың бір ғана тәсілмен шектеп қоймайды. Керісінше, оларды есептің дұрыс шешімін табуға арналған жолдарына жетелейді. Сонымен бірге компьютер қосымша құралдарды (теориялық анықтамалар, калькулятор, кестелер, жазу кітапшасы, көмекші есептерді автоматты түрде шығару) пайдалануды ұсынады, сол себепті оқушының есепті шығарудағы негізгі идеясынан ауытқымауына жағдай тудырады.

Жаттықтырушылар: теория, мысалдарды демонстрациялау, репетитормен жұмыс істеу, өзіндік жұмыс, өзін-өзі бақылау сияқты режимдерді қамтиды. 
Бақылау бағдарламалары - ол білім сапасын тексеруге (бағалауға) арналған бағдарламалық құралдар. Олар бақылау нәтижелерін тіркеуге, жинақтауға, шығаруға және статистикалық түрде талдау жасауға арналады.

Сәйкес бағдарламалық қамтамасыз етуі бар компьютер түріндегі мұғалім оқытудың өте куатты мүмкіндіктеріне ие болды деген пікірлер айтылып жүр. Онда компьютердің төмендегідей мүмкіндіктері ескеріледі, олар: оның түрлітүстілігі, мультипликациялық мүмкіндіктері, графикасы, дыбысы, оқу ақпараттарын кескіндеу мүмкіндігін кеңейтеді, сонымен бірге, әдеттегі көрнекілік принципін жаңа сапалы деңгейде іске асыруға мүмкіндік тудырады.

Компьютер оқытудың мотивациясын күшейту мүмкіндіктерін тудырады, яғни оқып үйренушілердің өзбетімен жұмыс істеуін белсенді етеді, білім мен біліктіліктердің жаңа жағдайлардағы қолданылу үрдісін күшейтеді, қажетті кері байланысты, бағаның шынайылығы мен нақтылығын, оқытуды жекешелендіруді т.б. қамтамасыз етеді. Компьютермен жұмыс істей отырып, оқушы өзінің алдына қойылған кез-келген оқу есептерінің шешімін аяғына дейін жеткізуіне мүмкіндік алады, себебі оған компьютер қажетті көмек бере алады, ал оқытудың ең тиімді жүйелерін пайдалана білгенде, оған есептердің тиімді жолмен шығарылу жағдайларын талқылауға мүмкіндік алады.

Дербес компьютерлер оқушының белсенділігін арттыруға көмектеседі. Окушының танымдық үрдісіндегі даму деңгейін есепке алудың ерекше жаңа мүмкіндіктері туады, сол сияқты берілген есептерді шығаруына көмектесетін мүмкіндіктер пайда болады.

Компьютерлерді пайдалану оқытудың мазмұнын анықтауға, оны модельдеуге алғышарттар тудырады. Зерттелетін үрдіске байланысты заңдылықтарды оқып-үйренуде оқушының модельдеуші бағдарламалық құралдарды пайдалана білуі оның жұмысындағы орталық кезең ретінде саналады. Пернетақтадан әр түрлі әрекеттерді бере отырып, оқушы жүйенің қандай күйге түсетінін бақылай алады, нәтижелерді талдай алады, нәтижеде шығатын заңдылықтармен фигуралардың қасиеттерін белгілі бір болжам түрінде 
тұжырымдайды, соңынан оны дәлелдейді. Осындай модельденетін жағдайлар оқып үйренушілер үшін проблемалық жағдайлар болуы мүмкін.

Бұл жағдайда оқытушының, оқушының зерттеу үрдісінде алған білімдеріне кеңесші ретіндегі рөлі арта түседі. Модельдеуші бағдарламаларды пайдалану оқу іс-әрекетінің әдіснамасын ғылыми-зерттеу жұмыстарының әдіснамасымен жақындасуына жағдай жасайды және оқушыларға оқу курсын меңгеруге мүмкіндік тудырып қана қоймай, модельдеу әдісінің өзінде меңгеруге мүмкіндік береді. Сонымен бірге, мектептегі зерттеу әдістері мен ғылыми зерттеу әдісі пара-пар емес екендігін ескерген жөн. Окушылардың зерттеу ісәрекеті, сұрақтар жүйесімен, танымдық есептермен және оқу тапсырмаларымен өрістейді және бағытталады.

Компьютер оқыту үрдісін басқару құралдарының диапазонын кеңейтеді, яғни оқушының өзіне-өзі сұрақ қоя алуынан бастап, оның оқу стратегиясының тиімді бағытын анықтауына дейін мүмкіндік береді, бұған баяндау деңгейін (абстрактылықтың дәрежесі, түсіндіруші мысалдардың саны т.с.с.), берілетін есептердің қиындық дәрежесін, оқу материалын баяндаудың бірізділігін қосады. Бұрынғы кездегі оқыту құралдарының ешқайсысы да оқушының есеп шығаруға көмектің қандай болатынын тұжырымдауына мүмкіндік тудырмайтын. Ең дамыған деген интелектуалдық жүйелердің міндеті - оқушылармен интерактивті түрде сұхбат жасау арқасында оқытудың байланысты стратегиясын жетілдіру болып табылады.

Компьютерді оқыту үрдісінде пайдалану - оқытуды жетілдірудің алғышарттары болғанымен, оның негативті әсерлерінің потенциалдық көзі болып табылады, олар төмендегі себептерден пайда болады:

- компьютерлік оқыту жүйелерін жасаушылардың тәжірибесінің жеткіліксіздігі;

- компьютердің потенциалдық мүмкіндіктерін толық іске асыра алмауы;

- компьютердің техникалық жүйе екендігіне байланысты кемістіктері.

Компьютерді оқытуда пайдалануда, көптеген сұхбаттық оқыту жүйелерінде кемістіктер болады. Олар: 
а) оқушыға берілетін оқыту әрекеттері (есептер, нұсқаулар, оку мәтіндері) көп жағдайларда олардың жеке мүмкіндіктерін ескермейді;

ә) оқушының ойлау іс-әрекетіндегі кейбір олқылықтарды есепке ала алмайды, соның салдарынан көрсетілуге тиісті көмек талап етілетін көмекпен үйлеспейді;

б) көптеген жағдайда ондай жүйелер ерекше шешімдерді бағалай және көптеген сұрақтарды түсіне алмайды, кейде сұрақты түсіну үшін оқушыға ұзақ уақыт керек болады.

Бұл жерде прогресс оқытудың ғылыми негіздерін жасауға, сол сияқты компьютердің интеллектуалдық мүмкіндіктерінің артуына байланысты. Компьютерді пайдалану «мұғалім-сынып» түріндегі бүтіндей жүйенің «оқушыкомпьютер» түріндегі жекелеген элементтерге бөлініп кетуіне әсер етеді. Сондықтан да, оқытудың компьютерлік технологиясын жобалаудағы арнайы мәселе - оқушы мен оқытушының бірлесе жұмыс істеуіне және олардың өзара түсінісуіне деген сұраныстарды іздестіру болып табылады, ал осы сияқты әдістерді құрастыру төмендегі бағыттар бойынша жасалуы тиіс:

- $\quad$ компьютерді пайдалануға негізделген окушылар мен мұғалімдердің оқыту үрдісіндегі өзара бірлесе жұмыс істеуіне арналған жағдайларды қалыптастыру;

- оқушылар тобының компьютермен жұмыс жасауын, олардың өзара жұмыс жасауын талап ететін ұжымдық жобаларды ұйымдастыру;

- $\quad$ компьютерлік және компьютерлік емес оқыту формаларының тиімді қатынастарын анықтау.

Оқыту үрдісінің тұтастығына компьютерлік оқыту жағдайында негізгі үш бағыт бойынша жетуге болады, олар:

- жекелеген оқушылардың танымдық белсенділігін басқара білу;

- «мұғалім-компьютер-оқушы» түріндегі жүйенің оқыту іс-әрекетін басқара білу;

- $\quad$ мұғалім мен оқушының, оқушылардың өзара бірлесе отырып, жұмыс істеуін басқару. 
Оку үрдісінде пайдаланылатын бағдарламалық құралдар әр түрлі көз қараста талдануы мүмкін. Жіктеуді негіздеу - білім беру жүйесінің қай саласында жататындығын түпкілікті зерттеу М.М. Буняевтің докторлық диссертациясында жүргізілген. Автор жіктеуді тиісті негізді бейнелейтін оқыту бағдарламалық құралдарын жіктеудің бір ғана тобының өзі әр түрлі білім салаларын, яғни, информатиканы, психологияны, дидактиканы қолдануды қажет ететіндігін айтады.

Оқыту бағдарламаларын сатылап жіктеуді құрастыруға бағытталған өңдемелер бар. Оқыту бағдарламаларын жіктеудің ғылыми негізделген түрі көп жақты және көп деңгейлі болу керектігі Е.И.Машбицтің [495] еңбегінде тұжырымдалған. Ол педагогикалық бағдарламалық құралдарды жіктеуде төмендегілерді ескеру қажеттігін айтады:

1) Окушы мен компьютер арасындағы тікелей өзара әрекеттің бар немесе жоқтығы;

2) Аяқталған оқыту фрагментінің барлық қажетті қызметтері іске асырылған ба, әлде жоқ па. Егер барлығы түгел болмаса, онда қандай қызметтер (қажетті іс-әрекетті демонстрациялау, есеп шығаруды басқарудың материалды бекітуге пайдаланылуы, бақылау т.с.с.) компьютерге жүктелгендігі;

3) Бағдарламаларда оқу тапсырмаларының қандай типтері келтірілген?

4) Оларда сұхбат жүзеге асырыла ма, жоқ па?

5) Оқушы тарапынан басқарыла ма?

6) Окушының жеке ерекшеліктері ескеріле ме, егер ескерілсе, онда рефлексивтік басқару қамтамасыз етіле ме?

Математикада компьютерді оқу құралы ретінде тиімді түрде пайдалану мәселесін қарастырғанда, педагогикалық бағдарламалық құралдарды жіктеуді олардың әдістемелік бағытталуы жағынан қарастырып, осы пәнді оның ерекшеліктері мен мазмұнын ескере отырып, ұйымдастыру мәселесі туындайды.

Бағдарламалық өнімді жобалауда жіктеу алдағы іс-әрекетті бағдарлауға қызмет етеді, әдістемелік жағынан тиімді бағдарламалық құралды жасауға, оның 
құрылымын анықтауға, оны оку үрдісін үйлесімді жоспарлауға, пайдалануға мүмкіндік тудырады.

Дидактикалық мәселелерді шешуге байланысты, оқушылардың icәрекетінің нәтижесінде іске асатын интеллектуалдық үрдістерге қатысты оқыту бағдарламаларының құрылымы анықталады. Дағдыларды қалыптастыру кезінде сызықтық бағдарламалардың рөлі зор; есеп шығаруды үйреткенде, сызықтық бағдарламалар алгоритмдік есептерді шығарғанда ғана қолданылады. Тармақталған және адаптивтік бағдарламалар есеп шығарушының ойлау ісәрекеті жартылай эвристикалық немесе эвристикалық үрдістерді қамтығанда ерекше мағынаға ие болады.

ҚБҚ - дың құрылымдарының бірнеше нұсқаларын қарастырайық.

\section{1 - нұсқа.}

Жалnы mun. Бағдарлама келесі блоктарды қамтиды: «енгізу», проблемалық жағдай, қимылдың бағытталған негізін (ҚБН) қалыптастыру, білімдерді және қорытуды қолдану, меңгерілгендердің диагностикасы, «шығу». Мұндай бағдарлама әртүрлі әдістемелік мәселелерді шешуде пайдаланылуы мүмкін.

\section{2 - нұсқа.}

Математикалық ұвымдарды қ̧алыптастыру. Ол мынандай блоктарды қамтиды: түсініктің маңызды және маңызды емес белгілерін айқындау, берілген математикалық объектінің анықтамасын тұжырымдау, осы фактіден объектінің анықтамаға сәйкес объектілер класына жататындығы жөнінде салдарлар алу.

\section{3 - нұсқа.}

Теоремаларды оқыл үйрену. Негізгі блоктары: теореманы оқып үйренуді негіздеу мен оның мазмұнын ашу, теореманың құрылымымен жұмыс істеу, дәлелдемені іздестіру, теореманы бекіту, теореманы қолдана отырып, есептер шығару.

\section{4 - нұска.}

Мектеп математика курсының жаңа алгоритмдері мен ережелерін меңгеру: онда әдеттегі проблеманы қоюды, алгоритмді (ережені) құрастыруды, 
алгоритмге енетін және оны орындау ретін меңгеруге арналған операцияларды өңдеуді, алгоритмнің қалыпты (алғашқы берілгендерді варияциялауда) және таныс емес жағдайдағы қолданылуын қамтитын «енгізу» мен «шығу» блоктары болады.

\section{5 - нұска.}

Оку іс-әрекеттерінің тәсілдерін құальптастыру. Мұндағы оқыту бағдарламасына: диагностика, тәсілді енгізу, тәсілді өңдеу, тәсілді қалыптастыру үрдісінде түзетулер мен оперативтік бақылау тәсілін қолдану, ауыстыруға үйрету және қорыту, қорытындыланған тәсілді бекіту, жаңа тәсілдерді табуға үйрету сияқты блоктар енеді.

\section{6 - нұсқа.}

Білімдердің кешеніне (оқу тақ̧ырыбы деңцгейінде) оқылту. Мұнда төмендегі блоктарды қамтитын интеллектуалдық оқыту жүйесі қажет, олар: оқушының динамикалық моделін құру, оқу есептерінің қойылымы және шешімдерді іздестіру, генерациялау, оқытушы әрекеттерді таңдау және ұсыну, оку есептерін шығарудың ағымдық және қорытынды бақылауы, жүйенің жұмыс режимін (Компьютер - тарапынан басқару, оқушы тарапынан басқару, оқу есептерін шығару үрдісіндегі алма-кезек басқару) анықтау.

Сөйтіп, оқытуды компьютерлендіру проблемасы бойынша ғылымиәдістемелік әдебиетті талдау бізге дербес компьютердің оқу құралы ретіндегі мәнін анықтауға мүмкіндік берді, оны оқу үрдісінде қолданудың артықшылықтарымен кемшіліктерін анықтады.

Қорыта келе, төмендегідей тұжырым жасай аламыз:

1. Компьютердің техникалық құрал ретінде мүмкіндіктерінің спектрі өте кең, бірақ олардың бар болуы дербес компьютерлерді оқу үрдісінде дұрыс және тиімді пайдаланылуына кепілдік бере алмайды. Осыған байланысты, жаңа ақпараттық технологияны оқыту үрдісіне пайдалануға бағытталған оқу тәрбие жұмысын сауатты түрде ұйымдастыру мәселесі өзекті және принциптік түрде маңызды. 
THEORETICAL FOUNDATIONS OF THE FUNCTIONING OF EDUCATION. WAYS TO IMPROVE THE EFFECTIVENESS OF EDUCATIONAL ACTIVITIES

Компьютерді оқыту құралы ретінде пайдалану үшін ол сәйкес бағдарламамен қамтамасыз етілуі керек. Сондықтан әртүрлі педагогикалық қызметтерді жүзеге асыру үшін оқытуға арналған бағдарламалық құралдарды жасау - компьютерлік оқытудың ең негізгі мәселелері болып табылады. 